\title{
Author Correction: Lineage tracing of acute myeloid leukemia reveals the impact of hypomethylating agents on chemoresistance selection
}

Francisco Caiado (1), Diogo Maia-Silva (1), Carolina Jardim, Nina Schmolka (1), Tânia Carvalho, Cláudia Reforço (D), Rita Faria (1D, Branka Kolundzija, André E. Simões, Tuncay Baubec (D), Christopher R. Vakoc, Maria Gomes da Silva, Markus G. Manz (1), Ton N. Schumacher (1), Håkan Norell \& Bruno Silva-Santos (D)

Correction to: Nature Communications https:/doi.org/10.1038/s41467-019-12983-z, published online 01 November 2019.

The original version of this Article omitted the following from the last sentence of the Acknowledgements:

UID/BIM/50005/2019, project funded by Fundação para a Ciência e a Tecnologia (FCT)/ Ministério da Ciência, Tecnologia e Ensino Superior (MCTES) through Fundos do Orçamento de Estado. This has now been corrected in both the PDF and HTML versions of the Article.

Published online: 26 November 2019

\footnotetext{
(c) (i) Open Access This article is licensed under a Creative Commons Attribution 4.0 International License, which permits use, sharing, adaptation, distribution and reproduction in any medium or format, as long as you give appropriate credit to the original author(s) and the source, provide a link to the Creative Commons license, and indicate if changes were made. The images or other third party material in this article are included in the article's Creative Commons license, unless indicated otherwise in a credit line to the material. If material is not included in the article's Creative Commons license and your intended use is not permitted by statutory regulation or exceeds the permitted use, you will need to obtain permission directly from the copyright holder. To view a copy of this license, visit http://creativecommons.org/licenses/by/4.0/.
}

(C) The Author(s) 2019 